\title{
Analisis Waktu Pelayanan Penerbitan Izin Gangguan (HO) Dinas Penanaman Modal dan Pelayanan Terpadu Satu Pintu (DPM-PTSP) Kota Banda Aceh
}

\author{
Samsul Anwar, Desfira Ahya, Afriyani, Nurhidayati, Reza Ariska, \\ RUdi WAHYUdi, NOVIRA ISWANI \\ Jurusan Statistika, Fakultas MIPA, Universitas Syiah Kuala Banda Aceh, Jl. T. Nyak \\ Arief. Kopelma Darussalam, Banda Aceh 23111 \\ Corresponding Author's E-mail: samsul.anwar@unsyiah.ac.id
}

\begin{abstract}
Abstrak
Data survival adalah data yang memiliki durasi waktu yang dimulai dari waktu awal sampai dengan waktu akhir ketika sebuah peristiwa yang diamati terjadi. Data lama waktu penerbitan perizinan izin gangguan atau Hinder Ordonantie (HO) di Dinas Penanaman Modal dan Pelayanan Terpadu Satu Pintu (DPM-PTSP) Kota Banda Aceh merupakan data survival dengan peristiwa yang diamati adalah proses penyelesaian penerbitan perizinan HO. Dengan demikian, data tersebut dapat dianalisis dengan menggunakan metode analisis survival. Penelitian ini menggunakan data sekunder yang dihimpun melalui berkas permohonan perizinan HO pada tahun 2016. Jumlah sampel yang digunakan dalam penelitian ini adalah sebanyak 36 kasus yang ditentukan dengan menggunakan rumus Slovin. Data survival tersebut dikategorikan tersensor apabila lama waktu penyelesaian proses perizinan HO lebih dari 7 hari. Metode analisis data yang digunakan dalam penelitian ini adalah Cox Proportional Hazard (Cox PH) model. Terdapat 11 variabel penjelas yang diduga mempengaruhi lamanya waktu penerbitan perizinan HO di DPM-PTSP Kota Banda Aceh. Analisis data dengan Cox PH model menunjukkan bahwa hanya 3 dari 11 variabel penjelas yang memiliki pengaruh yang signifikan. Ketiga variabel tersebut adalah biaya retribusi, kategori status gangguan dan luas tempat usaha. Sedangkan variabel lain yang berkaitan dengan latar belakang dan status pemohon terbukti tidak signifikan. Hal ini menunjukkan bahwa pelayanan di DPM-PTSP Kota Banda Aceh telah dilakukan secara jujur, berintegritas, profesional dan independen sesuai dengan capaian kinerja DPM-PTSP Kota Banda Aceh.
\end{abstract}

Kata kunci: analisis survival, cox proportional hazard, izin gangguan (HO), lama waktu penerbitan perizinan.

\begin{abstract}
Survival data is data that has a duration of time starting from the initial time to the end time when an observed event occurs. Length time data of completion of the disruption permit or Hinder Ordonantie(HO) in the One-door integrated investment and services office (DPM-PTSP) of Banda Aceh City is a survival data with the observed event is the process of completing the issuance of the disruption permit (HO). Therefore, the data could be analysed by using survival analysis methods. The study uses secondary dataset which is collected from the application files of HO in 2016. The number of sample uses in the study is 36 cases that determined by using Slovin formula. The survival data is categorised as a censoring dataset if the completion time of an application is longer than 7 days. The data analysis method used in this study is a Cox Proportional Hazard (Cox PH) model. There are 11 predictor variables that are suspected to affect the length time of issuance of the disruption permit (HO) at DPM-PTSP of Banda Aceh. Data analysis with Cox PH model shows that only 3 out of 11 predictor variables have significant effect on the model. Those variables are retribution fee, category of interference status, and the size of business place. While the others variables that associate with the background and status of the applicants are not significant. It shows that the services at the DPM-PTSP of Banda Aceh City has been done honestly, integrity, professional and independent in accordance with the performance achievements so far.
\end{abstract}

Keywords : cox proportional hazard, disruption permit (HO), duration time of the completion of a permit, survival analysis.

2000 Mathematics Subject Classification: $62 \mathrm{~N} 86$

Received: 2017-07-14, accepted: 2017-12-05. 


\section{Pendahuluan}

Menyelenggarakan pelayanan publik merupakan suatu kewajiban bagi aparatur negara untuk melayani masyarakatnya. Pelayanan publik merupakan upaya negara untuk memenuhi kebutuhan dasar dan hak-hak sipil setiap warga negara atas barang, jasa, dan pelayanan administrasi yang disediakan oleh penyelenggara pelayanan publik. Pada dasarnya, pelayanan publik mencakup tiga aspek, yaitu pelayanan barang, jasa, dan administratif. Wujud pelayanan administratif adalah layanan berbagai perizinan, baik yang bersifat non perizinan maupun perizinan. Izin merupakan perbuatan hukum administrasi negara yang bersegi satu yang mengaplikasikan peraturan dalam hal konkret berdasarkan persyaratan dan prosedur sebagaimana ditetapkan oleh ketentuan perundang-undangan yang berlaku. Penyelenggara pelayanan terpadu satu pintu memiliki tugas melaksanakan koordinasi, penyelenggaraan serta pelayanan administrasi dibidang perizinan dengan prinsip koordinasi, integrasi, sinkronisasi, simplifikasi dan keamanan.

Kota Banda Aceh sebagai Ibu Kota Provinsi Aceh merupakan salah satu wilayah administrastif dengan pelayanan terbaik di Provinsi Aceh. Dalam hal pelayanan perizinan, Kota Banda Aceh juga sudah menerapkan pola pelayanan perizinan terpadu melalui Dinas Penanaman Modal dan Pelayanan Terpadu Satu Pintu (DPM-PTSP) yang melaksanakan sebahagian kewenangan Walikota untuk penyelenggaraan pelayanan di bidang perizinan dan non perizinan. DPM-PTSP Kota Banda Aceh saat ini melayani 57 jenis perizinan dan 9 jenis izin penanaman modal [5].

Salah satu layanan perizinan yang paling sering dimanfaatkan oleh masyarakat adalah perizinan Gangguan/ Hinder Ordonantie (HO). Izin Gangguan (HO) adalah izin kegiatan usaha kepada orang pribadi atau badan di lokasi tertentu yang berpotensi menimbulkan bahaya kerugian dan gangguan, ketentraman dan ketertiban umum, tidak termasuk kegiatan/tempat usaha yang lokasinya telah ditunjuk oleh Pemerintah Pusat atau Daerah.

Beberapa landasan hukum yang dijadikan pedoman dalam pelayanan izin gangguan di Kota Banda Aceh adalah UU Gangguan stbl. Nomor 450 tahun 1940, Qanun Kota Banda Aceh Nomor 2 tahun 2008, Qanun Kota Banda Aceh Nomor 4 tahun 2010, Permendagri Nomor 27 tahun 2009, dan keputusan Walikota Banda Aceh Nomor 241 tahun 2000. Waktu maksimal penyelesaian penerbitan perizinan HO yang ditetapkan oleh DPM-PTSP Kota Banda Aceh adalah selama 7 hari kerja dengan tarif biaya administrasi yang bervariasi tergantung dari luas lahan yang akan dikeluarkan izinnya tersebut. Besaran biaya adminitratif pengurusan perizinan tersebut adalah sebesar Rp. 2.500/m untuk lahan dibawah $1000 \mathrm{~m}^{2}$, Rp. 2.000/m untuk luas lahan antar $1000-2000 \mathrm{~m}^{2}$, Rp. 1.500/m untuk luas lahan antara $2001-4000$ $m^{2}$, dan Rp. 1000/m untuk luas lahan diatas $4000 \mathrm{~m}^{2}$. Surat izin gangguan yang diterbitkan tersebut memiliki masa berlaku selama 3 tahun [6].

Melalui monitoring dan evaluasi internal, DPM-PTSP Kota Banda Aceh telah memperoleh penilaian Indek Kepuasan Masyarakat (IKM) dengan mutu pelayanan A sejak tahun 2011 dengan kinerja Sangat Baik [6]. Dalam rangka mewujudkan visi dan misi Kota Banda Aceh terutama misi dalam meningkatkan kualitas tata kelola pemerintahan yang baik, maka penilaian terhadap pelayanan di DPM-PTSP Kota Banda Aceh perlu dilakukan oleh pihak independen misalnya melalui penelitian atau kajian secara ilmiah lainnya. Penelitian mengenai analisis waktu pelayanan penerbitan perizinan HO merupakan salah satu permasalahan yang sangat menarik untuk dilaksanakan. Analisis survival Cox Proportional Hazard (Cox $\mathrm{PH}$ ) model merupakan salah satu metode statistik yang dapat digunakan untuk menjawab permasalahan ini. Anwar [1] menggunakan Cox PH model untuk mengidentifikasi faktor yang mempengaruhi lama waktu pembayaran angsuran pertama Program ZIS Produktif Baitul Mal Aceh. Dengan demikian, hasil penelitian di DPM-PTSP ini akan menjadi salah satu barometer pembanding terhadap prestasi yang telah diraih oleh DPM-PTSP Kota Banda Aceh selama ini. Selain itu, akan diketahui variabel apa saja yang mempengarui lamanya waktu penerbitan perizinan HO di DPM-PTSP Kota Banda Aceh. Identifikasi faktor-faktor ini menjadi sangat 
penting bagi DPM-PTSP Kota Banda Aceh dalam upaya peningkatan mutu pelayanan penerbitan perizinan kepada masyarakat secara umum, dan pelayanan penerbitan perizinan $\mathrm{HO}$ secara khusus. Berdasarkan latar belakang tersebut, dapat dirumuskan sebuah permasalahan yaitu faktor-faktor apa saja yang mempengaruhi lama waktu proses penerbitan perizinan HO di Dinas Penanaman Modal dan Pelayanan Terpadu Satu Pintu (DPM-PTSP) Kota Banda Aceh serta bagaimana kualitas pelayanan penerbitan perizian tersebut.

\section{Metode Penelitian}

2.1. Lokasi, Variabel Penelitian dan Jumlah Sampel. Penelitian ini dilakukan di Dinas Penanaman Modal dan Pelayanan Terpadu Satu Pintu (DPM-PTSP) Kota Banda Aceh yang beralamat di Jl. T. Abu Lam U, No. 7 Kota Banda Aceh. Jenis perizinan yang dianalisis dalam penelitian ini adalah Izin Gangguan/ Hinder Ordonantie (HO). DPM-PTSP Kota Banda Aceh menentapkan lama waktu maksimal penyelesaian perizinan HO adalah selama 7 hari kerja. Variabel respon yang digunakan dalam penelitian ini adalah lama waktu penyelesaian pengurusan perizinan $\mathrm{HO}(\mathrm{T})$, dengan 11 variabel penjelas yaitu: jenis kelamin pemilik usaha, status kawin pemilik usaha, kelompok umur pemilik usaha, kesamaan tempat tinggal, pekerjaan pemilik usaha, kategori indeks gangguan, biaya retribusi, kategori status gangguan, status badan hukum tempat usaha, kategori indeks lokasi, dan luas tempat usaha. Variabel penjelas tersebut merupakan variabel yang terdapat dalam formulir pendaftaran dan berkas kelengkapan permohonan perizinan HO di DPM-PTSP Kota Banda Aceh. Perhitungan jumlah sampel tersebut menggunakan rumus Slovin dengan batas toleransi kesalahan sebesar $20 \%$ dan dilakukan penambahan sampel (oversampling) sebesar 50\% dari jumlah sampel hasil perhitungan dengan rumus Slovin tersebut. Dimana jumlah seluruh permohonan perizinan HO di DPM-PTSP Kota Banda Aceh pada tahun 2016 adalah sebanyak 1,475 permohonan.

2.2. Metode dan Langkah Analisis Data. Data lamanya waktu pengurusan penerbitan perizinan $\mathrm{HO}$ merupakan data survival dengan kejadian yang diamati berupa terselesaikannya proses penerbitan perizinan HO yang diajukan oleh masyarakat di DPM-PTSP Kota Banda Aceh. Sehingga data durasi waktu penyelesaian perizinan HO tersebut dapat dianalisis dengan menggunakan pendekatan analisis survival. Metode analisis statistik yang digunakan dalam penelitian ini adalah analisis survival Cox Proportional Hazard (Cox PH) model. Tujuan penggunaan model ini adalah untuk mengetahui faktor-faktor penjelas yang mempengaruhi lamanya waktu penyelesaian pengurusan perizinan HO di DPM-PTSP Kota Banda Aceh. Pengolahan data dengan Cox PH model menggunakan software $R$ Versi 3.2.2. Adapun Langkah analisis dalam penelitian ini adalah sebagai berikut:

(1) Membangun Cox PH model untuk basemodel dengan memasukkan semua variabel penjelas dalam penelitian.

(2) Proses variable selections menggunakan metode backward elimination, yaitu dengan mengeluarkan variabel penjelas yang tidak signifikan pada tingkat signifikansi $\alpha=0.1$ dari model.

(3) Membangun Cox PH model final dengan menggunakan variabel penjelas hasil proses variable selections.

(4) Melakukan uji serentak, uji parsial, dan pengujian asumsi PH terhadap Cox PH model final pada tingkat signifikansi $\alpha=0.1$.

2.3. Analisis survival. Analisis survival adalah suatu metode statistik yang digunakan untuk menganalisis data dengan variabel respon berupa waktu sampai terjadinya suatu kejadian [3]. Variabel respon tersebut juga disebut dengan masa hidup, yang didefenisikan sebagai panjang interval waktu, $T$, dari saat pertama kali sampel/ unit berfungsi sampai dengan waktu terjadinya kegagalan fungsi pada sampel/ unit yang bersangkutan. Secara umum terdapat 4 fungsi dasar dalam analisis survival, yaitu probability density function (pdf), cummulative distribution function (cdf), fungsi survival dan hazard. Fungsi hazard, yang disimbolkan dengan $\mathrm{h}(\mathrm{t})$, merupakan salah satu fungsi penting dalam analisis survival. Fungsi ini menjelaskan laju 
kegagalan seketika dari sebuah sampel/ unit yang telah memiliki masa hidup $t$ satuan waktu [8]. Analisis survival secara umum memiliki tiga tujuan utama, yaitu: mengestimasi dan interpretasi fungsi hazard dan survival, membandingan fungsi hazard dan survival antar kelompok, dan mencari hubungan antara variabel respon dengan variabel penjelas yang mempengaruhinya.

2.4. Cox Proportional Hazard (Cox PH) Model. Cox Proportional Hazard (Cox PH) model dalam analisis survival digunakan untuk menganalisis hubungan antara variabel respon berupa data survival dengan variabel penjelasnya. Cox PH model dapat dirumuskan dengan persamaan sebagai berikut:

$$
h(t, X)=h_{0}(t) \exp \left(\sum_{i=1}^{p} \beta_{i} X_{i}\right)
$$

Matriks $X=\left(X_{1}, X_{2}, \ldots, X_{p}\right)$, merupakan kumpulan variabel penjelas dari Cox $\mathrm{PH}$ model. Terdapat dua komponen dalam persamaan (1), yaitu: $h_{0}(t)$ yang disebut dengan fungsi baseline hazard dan fungsi eksponensial dari penjumlahan linear fungsi $\beta_{i} X_{i}$. Komponen pertama adalah fungsi dari waktu $t$ yang tidak melibatkan variabel penjelas $X$. Sebaliknya, komponen kedua melibatkan variabel penjelas $X$, dan tidak berkaitan dengan variabel waktu t. Variable penjelas X dalam Cox PH model juga disebut dengan time independent [4]. Dalam Cox PH model, nilai hazard rasio dapat diestimasi melalui persamaan:

$$
\hat{H R}=\exp \left(\sum_{i=1}^{p} \hat{\beta}_{i}\left(X_{i}^{*}-X_{i}\right)\right.
$$

Dengan $X^{*}=\left(X_{1}^{*}, X_{2}^{*}, \ldots, X_{p}^{*}\right)$ dan $X=\left(X_{1}, X_{2}, \ldots, X_{p}\right)$. Terdapat tiga asumsi dalam Cox PH model, yaitu: efek regresi $\beta$ adalah konstan terhadap waktu (asumsi Proportional Hazard), merupakan kombinasi linear dari variabel penjelas (termasuk kemungkinan order yang lebih tinggi dan adanya interaksi antar variabel), dan link fungsi dalam Cox PH model adalah fungsi exponensial. Asumsi PH merupakan salah satu asumsi yang paling penting dalam Cox $\mathrm{PH}$ model. Asumsi tersebut menyatakan bahwa hazard rasio harus bernilai konstan terhadap waktu, atau secara matematis ditulis dengan persamaan:

$$
\hat{H R}=\frac{\hat{h}\left(t, X^{*}\right)}{\hat{h}(t, X)}=\hat{\theta}
$$

Komponen $\hat{\theta}$ merupakan sebuah statistik yang bernilai konstan dan tidak dipengaruhi oleh waktu t. Fungsi $\hat{h}\left(t, X^{*}\right)$ merupakan fungsi hazard untuk kelompok dengan nilai yang lebih besar (misalnya kelompok kontrol). Sedangkan $\hat{h}(t, X)$ merupakan fungsi hazard kelompok dengan nilai yang lebih kecil (misalnya kelompok perlakuan). Pengujian asumsi PH dapat dilakukan salah satunya dengan menggunakan goodness of fit test yaitu statistik Chi-square. Nilai $p$-value dari statistik Chi-square yang tidak signifikan mengindikasikan bahwa asumsi PH telah terpenuhi [4].

Selain asumsi PH, Cox PH model yang baik juga harus memenuhi pengujian statistik secara parsial dan serentak. Uji parsial dilakukan untuk menguji tingkat signifikansi koefisien masing-masing variabel dari Cox $\mathrm{PH}$ model melalui statistik Wald yang didefenisikan sebagai [7]:

$$
W=\left(\frac{\hat{\beta}_{j}}{\left(\operatorname{se}\left(\hat{\beta}_{j}\right)\right)}\right)^{2}
$$

Sedangkan uji serentak dilakukan dengan statistik Likelihood Ratio (LR) test. LR test digunakan untuk menguji tingkat signifikansi variabel penjelas secara bersamaan dalam Cox PH model melalui persamaan:

$$
\text { LRtest }=-2 \ln L_{R}-2 \ln L_{F}
$$

Dimana ln LR merupakan nilai Log likelihood dari model yang direduksi, dan ln LR merupakan nilai Log likelihood dari model yang lengkapnya [4]. 


\section{Hasil dan Pembahasan}

3.1. Karakteristik Sampel Penelitian. Data yang digunakan dalam penelitian ini terdiri dari dua buah tipe data, yaitu data berskala numerik dan data berskala kategorik. Data untuk variabel jenis kelamin, agama, status kawin, kelompok umur, kesamaan tempat tinggal, pekerjaan, kategori indeks gangguan, kategori status gangguan, status badan hukum, dan kategori indeks lokasi merupakan data yang berskala kategorik. Sedangkan data untuk variabel lama waktu penyelesaian perizinan HO, biaya retribusi, dan luas tempat usaha merupakan data yang berskala numerik. Dengan demikian, gambaran umum variabel dalam penelitian dibagi menjadi dua bagian, yaitu karakteristik sampel untuk data dalam bentuk kategorik yang ditampilkan pada Tabel 1, dan karakteristik sampel untuk data dalam bentuk numerik yang ditampilkan pada Tabel 2.

Berdasarkan Tabel 1, diketahui bahwa karakteristik sampel responden berdasarkan jenis kelamin lebih didominasi oleh responden berjenis kelamin laki-laki yaitu sebanyak 33 orang (91.67\%). Mayoritas responden berstatus sudah menikah yaitu sebanyak 27 orang $(75.00 \%)$. Jika dilihat berdasarkan kelompok umurnya, maka responden yang paling banyak berada pada kelompok umur 41-50 tahun yaitu sebanyak 11 orang (30.56\%). Selanjutnya, terdapat 26 orang responden $(72.22 \%$ ) yang memiliki tempat tinggal yang berbeda dengan lokasi yang akan diajukan perizinan gangguannya. Sedangkan sisanya 10 orang $(27.78 \%)$ beralamat tempat tinggal yang sama dengan lokasi pengajuan izin gangguannya. Mayoritas responden bekerja sebagai wiraswasta yaitu sebanyak 19 orang $(52.78 \%)$, sedangkan responden yang lainnya bekerja sebagai pedagang, karyawan swasta, IRT, pelajar/mahasiswa, dan ada beberapa responden yang tidak memiliki pekerjaan secara tetap.

Selanjutnya, jika dilihat berdasarkan kategori indeks gangguannya, diketahui sebanyak 20 orang responden $(55.56 \%)$ diantaranya mengajukan perizinan $\mathrm{HO}$ yang masuk kedalam indeks gangguan dengan kategori menengah. Kemudian, 21 orang responden $(58.33 \%)$ mengajukan perizinan dengan status gangguan kategori baru, sedangkan sisanya 15 orang mengajukan perizinan dengan status gangguan kategori perubahan dan perpanjangan. Dari 36 berkas permohonan izin gangguan, 19 (52.78\%) diantaranya merupakan permohonan izin gangguan untuk usaha yang berbadan hukum, sedangkan $17(47.22 \%)$ lainnya tidak memiliki badan hukum. Jika dilihat berdasarkan indeks lokasinya, maka mayoritas responden mengajukan perizinan gangguan untuk kategori lokasi perdagangan dan jasa yaitu sebanyak 33 orang (91.67\%), sedangkan yang mengajukan untuk kategori pemukiman hanya sebanyak 3 orang responden (8.33\%).

Karakteristik responden untuk data dengan skala numerik dilihat melalui 5 nilai statistik, yaitu nilai minimum, maksimum, rata-rata, median dan standar deviasi. Berdasarkan Tabel 2, diketahui bahwa data lama waktu penyelesaian perizinan HO memiliki nilai minimum dan maksimum sebesar 1 dan 12 hari kerja, dengan rata-rata lama waktu penyelesaian perizinannya selama 2.28 hari kerja dengan stadar deviasi sebesar 2.35 hari kerja. Hal ini menunjukan bahwa rata-rata lama waktu penyelesaian perizinan HO di DPM-PTSP Kota Banda Aceh masih dibawah waktu maksimal yang ditetapkan yaitu selama 7 hari kerja. Sebagai tambahan, nilai median lama waktu penyelesaian perizinan tersebut adalah selama 1 hari kerja. Untuk variabel biaya retribusi, nilai minimal dan maksimalnya adalah sebesar Rp. 120,000 dan Rp. 9,128,000, dengan nilai rata-rata sebesar Rp. 747,600 dan standar deviasi sebesar Rp. 1,743,600. Nilai median untuk variabel tersebut adalah sebesar Rp. 205,000. Untuk variabel penjelas yang terakhir yaitu luas tempat usaha, nilai minimal dan maksimalnya adalah seluas $16 \mathrm{~m}^{2}$ dan $4,564 \mathrm{~m}^{2}$. Rata-rata luas tempat usaha seluruh sampel responden adalah seluas $270.72 \mathrm{~m}^{2}$ dengan nilai standar deviasi sebesar $866.08 \mathrm{~m}^{2}$. Nilai tengah (median) untuk variabel luas tempat usaha tersebut adalah sebesar $36.0 \mathrm{~m}^{2}$.

3.2. Cox PH Model Perizinan HO. Variabel respon dalam analisis survival terdiri atas data tersensor dan data tidak tersensor. Dalam penelitian ini, data lama waktu penyelesaian perizinan HO dikatakan tersensor apabila perizinan tersebut diselesaikan dalam waktu lebih dari 7 hari kerja ( $T>7$ hari). Dengan demikian, data lama waktu penyelesaian perizinan 
TABEL 1. Karakteristik sampel untuk data kategorik

\begin{tabular}{|c|c|c|c|}
\hline Variabel & Keterangan & $\mathrm{n}$ & $\%$ \\
\hline \multirow[t]{3}{*}{$X_{1}$} & Jenis kelamin & & \\
\hline & 1: Perempuan & 3 & 8.33 \\
\hline & 2: Laki-laki & 33 & 91.67 \\
\hline \multirow[t]{3}{*}{$X_{2}$} & Status kawin & & \\
\hline & 1: Menikah & 27 & 75.00 \\
\hline & 2: Belum menikah & 9 & 25.00 \\
\hline \multirow[t]{6}{*}{$X_{3}$} & Kelompok umur (tahun) & & \\
\hline & $1:<=30$ & 9 & 25.00 \\
\hline & $2: 31-40$ & 9 & 25.00 \\
\hline & 3: $41-50$ & 11 & 30.56 \\
\hline & 4: $51-60$ & 6 & 16.67 \\
\hline & $5:>60$ & 1 & 2.78 \\
\hline \multirow[t]{3}{*}{$X_{4}$} & Kesamaan tempat tinggal & & \\
\hline & 1: Sama & 10 & 27.78 \\
\hline & 2: Tidak & 26 & 72.22 \\
\hline \multirow[t]{7}{*}{$X_{5}$} & Pekerjaan & & \\
\hline & 1: Wiraswasta & 19 & 52.78 \\
\hline & 2: Pedagang & 2 & 5.56 \\
\hline & 3: Karyawan swasta & 5 & 13.89 \\
\hline & 4: IRT & 3 & 8.33 \\
\hline & 5: Pelajar/mahasiswa & 6 & 16.67 \\
\hline & 6: Tidak bekerja & 1 & 2.78 \\
\hline \multirow[t]{4}{*}{$X_{6}$} & Kategori indeks gangguan & & \\
\hline & 1: Kecil & 14 & 38.89 \\
\hline & 2: Menengah & 20 & 55.56 \\
\hline & 3: Besar & 2 & 5.56 \\
\hline \multirow[t]{4}{*}{$X_{8}$} & Kategori status gangguan & & \\
\hline & 1: Baru & 21 & 58.33 \\
\hline & 2: Perubahan & 7 & 19.44 \\
\hline & 3: Perpanjangan & 8 & 22.22 \\
\hline \multirow[t]{3}{*}{$X_{9}$} & Status badan hukum & & \\
\hline & 1: Berbadan hukum & 19 & 52.78 \\
\hline & 2: Tidak & 17 & 47.22 \\
\hline \multirow[t]{3}{*}{$X_{1} 0$} & Kategori indeks lokasi & & \\
\hline & 1: Perdagangan dan jasa & 33 & 91.67 \\
\hline & 2: Pemukiman & 3 & 8.33 \\
\hline
\end{tabular}

TABEL 2. Karakteristik responden untuk data numerik

\begin{tabular}{clccccc}
\hline Variabel & Keterangan & Min & Mak & Mean & Median & SD \\
\hline $\mathrm{T}$ & Lama waktu penyelesaian (hari) & 1 & 12 & 2.28 & 1.00 & 2.35 \\
$\mathrm{X} 7$ & Retribusi (puluhan ribu) & 12 & 912.80 & 74.76 & 20.50 & 174.36 \\
$\mathrm{X} 11$ & Luas tempat usaha $\left(\mathrm{m}^{2}\right)$ & 16 & 4,564 & 270.72 & 36.00 & 866.08 \\
\hline
\end{tabular}

HO yang tidak melebihi 7 hari dikategorikan sebagai data tidak tersensor. Data dengan status tersensor dan tidak tersensor akan mempengaruhi pembentukan model Cox PH, sehingga penentuan batasan maksimal waktu kejadian penyelesaian perizinan HO merupakan hal yang sangat penting dalam penelitian ini. Tabel 3 memuat beberapa statistik penting berupa nilai beta, hazard rasio, statistik Wald (Z), dan p-value dari Cox PH basemodel yang terdiri atas semua variabel penjelas didalamnya. 
Untuk mendapatkan model yang terbaik, terdapat 3 pengujian statistik yang harus dilakukan terhadap sebuah Cox PH model. Pertama, pengujian secara serentak melalui statistik Likelihood Ratio (LR) test. Kedua pengujian secara parsial melalui statistik Wald, dan ketiga pengujian asumsi PH melalui statistik Chi Square. Model Cox PH yang baik adalah model yang telah melewati ketiga pengujian statistik tersebut. Selain itu, proses variable selection perlu diterapkan untuk model dengan jumlah variabel penjelas yang banyak. Hal ini dilakukan untuk mendapatkan variabel penjelas yang benar-benar signifikan dalam Cox PH model. Pengujian secara parsial melalui statistik Wald, dapat digunakan sebagai kriteria dalam proses variable selection tersebut. Variabel penjelas dengan nilai statistik Wald yang tidak signifikan akan dikeluarkan dari model.

Tabel 3 menunjukkan bahwa dari kesebelas variabel penjelas dalam basemodel tersebut, 4 diantaranya memiliki nilai $p$-value $<0.1$ pada proses variable selection tahap pertama. Keempat variabel penjelas tersebut adalah kesamaan tempat tinggal dengan lokasi usaha, besaran biaya retribusi, kategori status gangguan dan luas tempat usaha. Selanjutnya, keempat variabel tersebut akan dimasukan kedalam model baru untuk mendapatkan Cox PH model hasil seleksi tahap pertama. Proses selection variable tahap kedua dilakukan dengan memilih variabel penjelas dengan nilai $p$-value $<0.1$ dari Cox PH model hasil seleksi variabel tahap pertama. Berdasarkan kriteria tersebut, diketahui bahwa hanya 1 buah variabel penjelas yang memiliki nilai $p$-value $>0.1$ yaitu variabel kesamaan tempat tinggal dengan lokasi usaha. Sehingga, variabel penjelas tersebut dikeluarkan dari model untuk mendapatkan Cox PH model final hasil variable selection tahap kedua yang memuat 3 variabel penjelas didalamnya. Ketiga variabel penjelas dalam Cox $\mathrm{PH}$ model final tersebut adalah besaran biaya retribusi, kategori status gangguan dan luas tempat usaha. Cox PH model final hasil variable selection tersebut ditampilkan dalam Tabel 4.

Berdasarkan Tabel 4, Cox PH model final untuk variabel respon lama waktu penyelesaian perizinan HO di DPM-PTSP Kota Banda Aceh dapat ditulis dalam persamaan matematis:

$$
h(t, X)=h_{0}(t) \exp \left(0.023 X_{7}+1.628 X_{8}(2)+0.484 X_{8}(3)+0.042 X_{11}\right)
$$

Cox PH model final untuk perizinan $\mathrm{HO}$ terdiri atas 3 buah variabel penjelas dengan uji serentak melalui LR test yang signifikan pada $\alpha=0.1$. Nilai likelihood ratio test dari model tersebut adalah sebesar 13.2 dengan $p$-value sebesar 0.010. Selanjutnya, 2 buah variabel penjelas dengan skala numerik dan 1 kategori dari variabel penjelas dengan skala kategorik tersebut juga telah signifikan secara parsial melalui statistik Wald yang ditandai oleh nilai $p$ value $<0.1$. Selain pengujian secara serentak dan parsial, Cox PH model tersebut juga perlu dilakukan pengujian asumsi Proportional Hazard (PH) yang mensyaratkan bahwa nilai hazard rasio untuk ketiga variabel tersebut bernilai konstan dan independen terhadap waktu. Sebuah variabel penjelas dikatakan memenuhi asumsi $\mathrm{PH}$ apabila memiliki nilai statistik Chi-square yang tidak signifikan pada $\alpha=0.1$. Nilai Chi-square beserta $p$-value untuk ketiga variabel penjelas tersebut juga disajikan dalam Tabel 4 kolom 7 dan 8. Berdasarkan Tabel 4, terlihat bahwa kedua variabel penjelas dengan skala numerik dan 1 kategori dari variabel penjelas yang berskala kategorik dalam Cox PH model final memiliki nilai $p$-value $>0.1$. Sehingga dapat disimpulkan bahwa ketiga varibel penjelas tersebut telah memenuhi asumsi PH. Dengan demikian, Cox PH model final tersebut telah memenuhi semua persyaratan sebagai Cox $\mathrm{PH}$ model yang baik.

Berikut adalah interpretasi dari Cox PH model final berdasarkan nilai hazard rasio dari masing-masing variabel penjelasnya.

(1) Variabel biaya retribusi. Proses penyelesaian perizinan HO untuk selisih biaya retribusi sebesar Rp.10,000 cenderung mengalami pengurangan resiko sebesar $(1-0.977) \%=$ $2.3 \%$ untuk lebih cepat selesai. Sebagai ilustrasi, perizinan HO dengan biaya retribusi sebesar Rp. 500,000 cenderung mengalami pengurangan resiko untuk cepat selesai sebesar $2.3 \%$ dibandingkan dengan perizinan dengan biaya retribusi sebesar Rp. 490,000. 
TABEL 3. Cox PH model awal (basemodel)

\begin{tabular}{|c|c|c|c|c|c|}
\hline Variabel & Keterangan & Beta & Hazard & Wald & $p$-value \\
\hline \multirow[t]{2}{*}{$\mathrm{X} 1$} & $\begin{array}{l}\text { Jenis kelamin } \\
\text { 1: Perempuan }(\mathrm{R})\end{array}$ & & & & \\
\hline & 2: Laki-laki & 1.103 & 3.012 & 1.32 & 0.186 \\
\hline \multirow[t]{2}{*}{$\mathrm{X} 2$} & $\begin{array}{l}\text { Status kawin } \\
\text { 1: Menikah (R) }\end{array}$ & & & & \\
\hline & 2: Belum menikah & -2.534 & 0.079 & -1.63 & 0.103 \\
\hline \multirow[t]{5}{*}{$\mathrm{X} 3$} & $\begin{array}{l}\text { Kelompok umur (tahun) } \\
1:<=30(\mathrm{R})\end{array}$ & & & & \\
\hline & 2: $31-40$ & -0.058 & 0.943 & -0.05 & 0.959 \\
\hline & 3: $41-50$ & -1.520 & 0.219 & -1.46 & 0.144 \\
\hline & 4: $51-60$ & -0.448 & 0.639 & -0.48 & 0.630 \\
\hline & $5:>60$ & -0.275 & 0.760 & -0.16 & 0.870 \\
\hline \multirow[t]{2}{*}{$\mathrm{X} 4$} & $\begin{array}{l}\text { Kesamaan tempat tinggal } \\
\text { 1: Sama }(\mathrm{R})\end{array}$ & & & & \\
\hline & 2: Tidak & -1.491 & 0.225 & -2.24 & 0.025 \\
\hline \multirow[t]{6}{*}{$\mathrm{X} 5$} & $\begin{array}{l}\text { Pekerjaan } \\
\text { 1: Wiraswasta (R) }\end{array}$ & & & & \\
\hline & 2: Pedagang & 1.048 & 2.853 & 1.19 & 0.234 \\
\hline & 3: Karyawan swasta & 0.636 & 1.889 & 0.69 & 0.491 \\
\hline & 4: IRT & NA & NA & NA & NA \\
\hline & 5: Pelajar/mahasiswa & 1.338 & 3.810 & 0.69 & 0.490 \\
\hline & 6: Tidak bekerja & 0.941 & 2.563 & 0.48 & 0.628 \\
\hline \multirow[t]{3}{*}{$\mathrm{X} 6$} & $\begin{array}{l}\text { Kategori indeks gangguan } \\
\text { 1: Kecil (R) }\end{array}$ & & & & \\
\hline & 2: Menengah & -0.379 & 0.685 & -0.59 & 0.552 \\
\hline & 3: Besar & -3.011 & 0.049 & -0.77 & 0.440 \\
\hline $\mathrm{X} 7$ & Retribusi & -0.032 & 0.969 & -1.99 & 0.046 \\
\hline \multirow[t]{3}{*}{$\mathrm{X} 8$} & $\begin{array}{l}\text { Kategori status gangguan } \\
\text { 1: Baru }(\mathrm{R})\end{array}$ & & & & \\
\hline & 2: Perubahan & 2.318 & 10.158 & 2.45 & 0.014 \\
\hline & 3: Perpanjangan & 1.479 & 4.390 & 2.26 & 0.024 \\
\hline X9 & $\begin{array}{l}\text { Status badan hukum } \\
\text { 1: Berbadan hukum (R) }\end{array}$ & & & & \\
\hline & $\begin{array}{l}\text { 2: Tidak } \\
\text { Kategori indeks lokasi }\end{array}$ & 1.216 & 3.373 & 1.63 & 0.102 \\
\hline $\mathrm{X} 10$ & $\begin{array}{l}\text { 1: Perdagangan dan jasa }(\mathrm{R}) \\
\text { 2: Pemukiman }\end{array}$ & -0.416 & 0.660 & -0.37 & 0.714 \\
\hline X11 & Luas tempat usaha $\left(m^{2}\right)$ & 0.067 & 1.069 & 1.81 & 0.071 \\
\hline
\end{tabular}

Likelihood ratio $(\mathrm{LR})$ test $=36.5 ; p$-value $=0.009 ;(\mathrm{R})$ : Reference kategori

(2) Variabel kategori status gangguan. Proses penyelesaian perizinan HO untuk kasus status gangguan kategori perubahan cenderung mengalami peningkatan resiko sebesar $(5.095-1) \%=409.5 \%$ untuk lebih cepat selesai dibandingkan dengan perizinan $\mathrm{HO}$ untuk kasus status gangguan kategori baru.

(3) Variabel luas tempat usaha. Proses penyelesaian perizinan HO untuk selisih luas tempat usaha sebesar $10 \mathrm{~m}^{2}$ cenderung mengalami peningkatan resiko sebesar $(1.043-1) \%$ $=4.3 \%$ untuk lebih cepat selesai. Sebagai ilustrasi, perizinan HO dengan luas tempat usaha sebesar $110 \mathrm{~m}^{2}$ cenderung beresiko $4.3 \%$ lebih cepat selesai dibandingkan dengan perizinan HO dengan luas tempat usaha sebesar $100 \mathrm{~m}^{2}$. 
TABEL 4. Cox PH model final dan pengujian asumsi PH

\begin{tabular}{cccccccc}
\hline Variabel & Keterangan & \multicolumn{3}{c}{ Pengujian parsial model } & \multicolumn{2}{c}{ Pengujian asumsi PH } \\
& & Beta & Hazard & Wald & $p$-value & Chi- square & $p$-value \\
\hline X7 & Retribusi & 0.023 & 0.977 & -2.36 & 0.018 & 0.424 & 0.515 \\
X8 & Kategori status gangguan & & & & & & \\
& 1: Baru (R) & & & & & - & \\
& 2: Perubahan & 1.628 & 5.095 & 2.84 & 0.005 & 1.084 & 0.298 \\
& 3: Perpanjangan & 0.484 & 1.623 & 1.07 & 0.283 & 2.517 & 0.113 \\
X11 & Luas tempat usaha $\left(m^{2}\right)$ & 0.042 & 1.043 & 2.22 & 0.026 & 0.341 & 0.559 \\
\hline \multicolumn{2}{c}{ Likelihood ratio $(\mathbf{L R})$ test $=\mathbf{1 3 . 2} ; \boldsymbol{p}$-value $=\mathbf{0 . 0 1 0} ;(\mathbf{R}):$ Reference kategori }
\end{tabular}

Likelihood ratio $(\mathrm{LR})$ test $=13.2 ; p$-value $=0.010 ;(\mathrm{R})$ : Reference kategori

Selain analisis dan interpretasi terhadap variabel penjelas yang signifikan dalam Cox $\mathrm{PH}$ model, variabel penjelas yang tidak signifikan juga sangat menarik untuk dikaji. Hasil penelitian ini menunjukkan bahwa seluruh variabel penjelas yang berkaitan dengan latar belakang dan status pemilik tempat usaha tidak ada yang berpengaruh signifikan secara statistik. Hal tersebut menunjukkan bahwa latar belakang dan status pemilik usaha tidak mempengaruhi lamanya waktu penyelesaian proses penerbitan perizinan izin gangguan (HO) di DPM-PTSP Kota Banda Aceh. Dengan demikian, dapat dikatakan bahwa aparatur yang melaksanakan tugas pelayanan publik di DPM-PTSP Kota Banda Aceh telah bekerja secara jujur, berintegritas, profesional dan independen dalam melayani masyarakat. Sesuai dengan Kode Etik DPM-PTSP Kota Banda Aceh [2], jujur berarti dapat dipercaya dalam perkataan dan tindakan, berintegritas berarti memiliki sikap dan tingkah laku yang bermartabat dan bertanggungjawab, professional dalam hal melakukan pekerjaan sesuai dengan tugas dan keahlian serta mencegah terjadinya benturan kepentingan dalam pelaksanaan tugas, dan independen yang menunjukkan bahwa aparatur tidak terpengaruh dan bersikap netral dalam melaksanakan tugasnya. Hal ini menegaskan bahwa pelayanan di DPM-PTSP Kota Banda Aceh tidak mengindikasikan terjadinya penyalahgunaan wewenang maupun praktek Korupsi, Kolusi dan Nepotisme (KKN). Masyarakat yang mengajukan permohonan perizinan di DPM-PTSP Kota Banda Aceh dilayani secara jujur, berintegritas, profesional dan independen tanpa memandang status dan kedudukan dari pemohon. Hasil penelitian ini mendukung capaian prestasi yang telah diraih DPM-PTSP Kota Banda Aceh selama ini.

\section{Simpulan}

Hasil penelitian ini menjadi salah satu barometer pembanding atas capaian kinerja pelayanan publik di DPM-PTSP Kota Banda Aceh selama ini. Dari 11 variabel penjelas yang diteliti dalam penelitian ini, hanya 3 diantaranya yang berpengaruh signifikan terhadap variabel respon lama waktu penyelesaian perizinan HO di DPM-PTSP Kota Banda Aceh. Ketiga variabel tersebut adalah biaya retribusi, kategori status gangguan dan luas tempat usaha. Lebih lanjut, aparatur DPM-PTSP Kota Banda Aceh telah bekerja secara jujur, berintegritas, profesional dan independen dalam melayani masyarakat sesuai dengan penilaian Indek Kepuasan Masyarakat (IKM) beberapa tahun terakhir. Hal ini dibuktikan dengan tidak terdapatnya kaitan antara latar belakang dan status pemohon dengan lama waktu penyelesaian perizinan HO yang mereka ajukan.

\section{DAFtar Pustaka}

[1] Anwar, S., dkk., 2017, Analisis Faktor yang Mempengaruhi Lama Waktu Pembayaran Angsuran Pertama Program ZIS Produktif Baitul Mal Aceh, Jurnal Statistika: Forum Teori dan Aplikasi Statistika, 17(2), 53-61. 
[2] DPM-PTSP Kota Banda Aceh, 2017, Keputusan Kepala Dinas DPM-PTSP Kota Banda Aceh tentang Kode Etik Aparatur pada Dinas Penanaman Modal dan Pelayanan Terpadu Satu Pintu Kota Banda Aceh. Banda Aceh: DPM-PTSP Kota Banda Aceh.

[3] Kleinbaum, D.G., dan Klein, M., 2005, Survival Analysis, Edisi Kedua, New York: Springer Science Business Media, Inc.

[4] Kleinbaum, D.G., dan Klein, M., 2011, Survival Analysis: A Self-Learning Text, Edisi Kedua, New York: Springer, Halaman 94, 100.

[5] KPPTSP Banda Aceh, 2014, Buku Perizinan KPPTSP. Banda Aceh: KPPTSP Banda Aceh.

[6] KPPTSP Banda Aceh, 2015, Buku Perizinan Online: perizinan.bandaacehkota.go.id. Banda Aceh: KPPTSP Banda Aceh.

[7] Machin, D., Cheung, Y.B. dan Parmar, M.K.B., 2006, Survival Analysis: A Practical Approach, Edisi Kedua, London: John Wiley \& Sons Ltd., Halaman 94-124.

[8] Zacks, S., 1991, Introduction to Reliability Analysis Probability Models and Statistical Methods, New York: Springer text in Statistics. 